\section{LOVE OF THE ROAD} AND MEMORIES IN THE WATER: AFFECTS IN INFRASTRUCTURAL

\section{SPACES IN GORSKI KOTAR}

Original scientific paper Submitted: 3. 1. 2019 Accepted: 27. 9. 2019. DOI: $10.15176 /$ vol56no205 UDK 114(497.651) 94(497.5) 913

\title{
MORANA JAREC
}

Institute for Anthropological Research, Zagreb

\begin{abstract}
The article presents various ways of transformation of infrastructural spaces in the region of Gorski Kotar (Croatia) into a symbolic place, through affects of the local population. The research is conducted within the context of the Lujzijana road, dating from the beginning of the $19^{\text {th }}$ century, connecting the cities of Rijeka and Karlovac, and a dam with its vast artificial lake, built in the 1950s in the village of Lokve. Certain events, scenes, situations, narratives, practices and reactions as generators and consequences of affects are used as a base for the analysis. The study shows that people experience different kinds of affects in relation to both physical features of infrastructure and its influences, which are then expressed through literature, in plain conversations, through individual practice and organized activities. While the Lujzijana road, as an instance of cultural heritage, provokes feelings of love and respect, the dam and the lake create a hybrid place composed of joyous memories related to the time of the construction of the dam, as well as sad memories of the lost villages, flooded by the lake.
\end{abstract}

Keywords: affect, infrastructure, place-making, Gorski Kotar

CHERISH ME

Cherish me and surely you will remember me for a long time

Cherish me even when cold rains fill the nights with sorrow

Cherish me when the heat comes and blizzards sweep

Cherish me when others cease to cherish me

Cherish me when letters cease to come, from those close and

those far away

Cherish me even when you tire of it, like anyone who cherishes

what is precious

Cherish me and surely you will remember me for a long time

Do not stop when they tell you that the other one came 
And that it is time you dedicate to the younger one May young and old disbelieve that memories of me no longer exist May those who believe this and readily declared me worthless tire Cherish me and surely you will remember me for a long time Excerpt from the poem by Matija Glad (unpublished)

\section{INTRODUCTION}

The article focuses on two pieces of infrastructure in Gorski Kotar (central Croatia): the first is a transit infrastructure, the Lujzijana road (built 1803-1811), connecting the cities of Rijeka and Karlovac and passing through the region of Gorski Kotar in Croatia, and the second is a dam and artificial lake, located in the village of Lokve (built 1952-1955). The road, the dam and the lake are physically and affectively intertwined, and so are their influences. Throughout history as well as today, the Lujzijana road has been producing ambivalent influences and meanings for the inhabitants alongside the road and its users: at the time of its construction, it brought demographic and economic prosperity to the region, but when automobile transit suddenly decreased because of the construction of the new motorway in this area in the period of 1996-2008, it also caused a reduction of economic opportunities, especially in transit tourism. Because of its remarkable structural characteristics for the time of its construction and the fact that it was an initiator of progress, it is now considered a landmark. In contrast, the construction of the dam led to its artificial lake flooding parts of several villages and parts of the Lujzijana road, which had a major effect on the organization of space in terms of bypass roads, changes in practices and lifestyle, and again, the emergence of new meanings and affects.

The poem from the beginning of the article, entitled Čuvajte me [Cherish me], ${ }^{2}$ is about the Lujzijana road. By connecting the notion of a poem to ordinary, everyday materiality

\footnotetext{
${ }^{1}$ The construction of the Rijeka - Zagreb motorway started in 1970: the section Orehovica - Kikovica was completed in 1971, and the section Karlovac - Zagreb in 1972. In 1982, the section Kikovica - Oštrovica was opened for traffic but only as a semi-motorway. Work on motorway construction resumed in 1996. Motorway sections in the region of Gorski Kotar are (from west to east): Oštrovica - Vrata (completed in 1996), Vrata - Delnice (opened as a semi-motorway in 1996 and completed in full profile in 2008), Delnice - Kupjak (completed in 1997), Kupjak - Vrbovsko (most of the route was completed in 2003 and in 2006 the section was completed in full profile) and Vrbovsko - Bosiljevo (part of the section was completed in 2003 and in 2004 the section was completed in full profile). The Rijeka - Zagreb motorway was fully functional by 2004 and the cities of Rijeka and Zagreb were connected by a single route. However, parts of the motorway were still under construction and it was completed and officially opened in 2008 (Glad 2014: 138-140).

2 The poem is actually a modification of the love poem entitled "Wait for me" written in 1941 by Russian writer Konstantin Simonov. It was recited by Matija Glad, PhD, a traffic engineer from Belo Selo in Gorski Kotar. He recited the poem during a tour around the Lujzijana road that I participated in. Here is the original poem in Croatian: "Čuvajte me; Čuvajte me i ja ću vam sigurno u sjećanju ostati dugo; Čuvajte me i kad hladne kiše noći ispune tugom; Čuvajte i kad vrućine dođu i kada mećave brišu; Čuvajte i kada me drugi ne budu čuvali više; Čuvajte i kada pisati prestanu oni izbliza i oni daleko; Čuvajte i kada vam čuvanje dojadi kao i svima koji čuvaju vrijedno; Čuvajte me i ja ću vam sigurno u sjećanju ostati dugo; Ne sustajte kada vam kažu kako stigla je druga; I kako je vrijeme da zaboravite i pažnju posvetite mlađoj; Nek ne vjeruju ni mladi ni stari
} 
such as a road, we can recognize the phenomenon of emotional relationship towards infrastructure that this article seeks to explore. Other than the existence of the poem itself, with its emotive verses, the context and the atmosphere is important: the origin and profession of the author, the setting where it was performed and the reactions it provoked. Local population's affects expressed through narratives, as well as actions, contexts, atmosphere and reactions, will be interpreted in this article to show how the physical landscape with its specific infrastructure is transformed into a symbolic space.

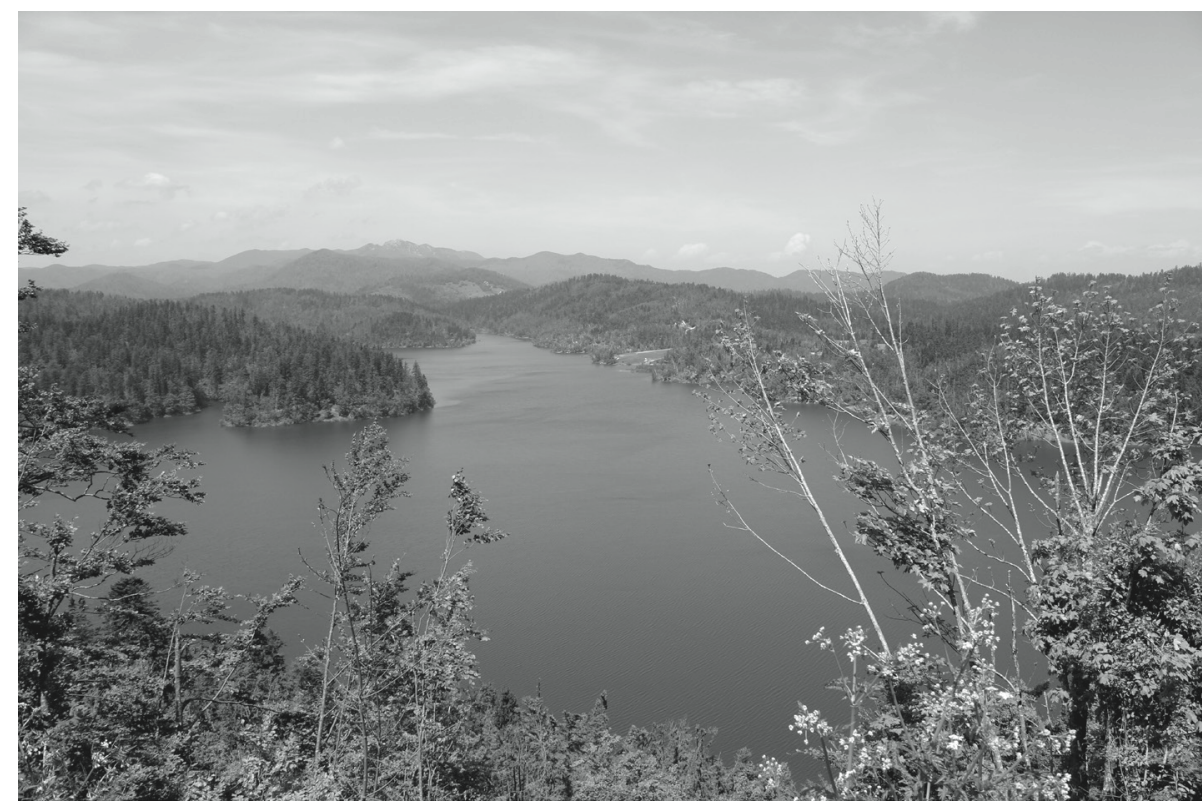

Picture 1. Lokvarsko (Omladinsko) jezero [Lokve/Youth lake] (photograph taken by Morana Jarec on 19 May 2015)

\section{METHODOLOGY}

Unpublished poetry ${ }^{3}$ and literature from the local library (Asić Klobučar 2002, Laloš 2007, Strohal 1993 [1935], Pleše 2004) served as a source for the analysis of narratives. Lokvarski zbornik [The Lokve Anthology] (Pleše 2004) is also particularly interesting because of its significance in transmitting affect. When the lake was drained because of the work

da uspomene na mene više ne postoje; I neka se umore oni koji misleći tako bezvrijednom me proglasiše lako; Ali čuvajte me i ja ću vam sigurno u sjećanju ostati dugo."

${ }^{3}$ Unpublished poetry that is used for analysis refers to the poem Cuuvajte me [Cherish me], cited at the beginning of the article, and recited by Matija Glad during a tour of the Lujzijana road. The other unpublished poem that I analyze in this article is Život za život [Life for life] by Nikola Čulinović, an engineer from Zagreb who came to the village of Mrzla Vodica to work on dam construction. The poem was given to me during one of the interviews in Mrzla Vodica. 
on the control and protection of the hydroelectric power plant in 2001, a walk on the lake bottom was organized to document the ruins, trajectories of the flooded Lujzijana road and of stream beds as well as the memories of the people who used to live there. On that occasion, school children wrote short stories and poems and interviewed people that once lived in the flooded villages and those who participated in the construction of the dam. Children's work and interviews were published in Lokvarski zbornik, so some portions of the interviews on that topic are cited from it.

In addition to published and unpublished data, participant observation and interviews with the local population ${ }^{4}$ provided insights that helped in the interpretation of data. Several short-term fieldwork projects were conducted in the villages of Lokve and Mrzla Vodica in 2015 and 2018. Because affect, as a concept, includes the corporeal and the cognitive, emotions and reactions as a result of cultural and social processes (Škrbić Alempijević et al. 2016: 71), certain events, scenes, situations, narratives, practices and reactions as generators and consequences of affects were used as a base for the analysis. A significant part of the fieldwork conducted during a tour organized around the Lujzijana road as a landmark. The tour was intended for local organizations and individuals with the goal of familiarizing them with the existing tourism products and services and possibilities for their tourist exploitation in the future. Locals with knowledge of each location on the tour would talk to other locals as though they were tourists, so the tour had a very informal atmosphere. Many nostalgic memories, romantic and poetic descriptions of the Lujzijana road, the dam and the lake emerged in conversation. Photographs that complemented the research were taken during fieldwork, provided by the local population and scanned from photo albums.

In studying affect, methods of qualitative research have to be adjusted by employing different analytical emphases and a different perspective on cultural and social phenomena and processes, which are then visible in the formulation of the research questions (Škrbić Alempijević et al. 2016: 79). The main goal of this research is to show how the physical landscape with infrastructure is transformed into symbolic spaces and how symbolic meanings are inscribed in these infrastructural spaces in the region of Gorski Kotar. This case study seeks to answer several research questions: what kinds of interactions exist between people and their surroundings; what kinds of effects infrastructural spaces generate and how they affect the population; how the population, in the context of those effects, conceptualizes and acts in the infrastructural spaces; how those effects are experienced and narrativized; how affects are put into practice and transmitted; does infrastructure stimulate memories and how affects depend on the political, economic, and social context. Precisely because affects should not be considered independently of history and the social and political context, a short overview of the research space follows.

${ }^{4}$ Some of the interlocutors chose to remain anonymous. To ensure this, professions, places of residence or age of the interlocutors have not been used, because of the small population size of the research area. However, where anonymity was not an issue and when I considered it of significance for the analysis, names and professions have been mentioned (such as in case of Matija Glad because of his origin and profession, and Mirjana Pleše, a school teacher, the initiator of many activities related to the dam and the lake). 


\section{GORSKI KOTAR}

Gorski Kotar is a mountainous region situated in the northeast of the Primorsko-Goranska County in Croatia and it includes three towns and six municipalities. ${ }^{5}$ Settlements are dispersed with a relatively small number of inhabitants. ${ }^{6}$ This part of Croatia is economically poorly developed and still subject to strong depopulation.? Because of rapid industrialization and urbanization, the 1960s and 1970s saw the "exodus of the Gorans [inhabitants of the region]" directed to larger urban centres in Croatia and Western Europe (Lajić and Klempić Bogadi 2010: 193-194). Since then, Gorski Kotar has been characterized by extremely poor demographic trends, which show that Gorski Kotar reached almost extreme depopulation and in the framework of such movements, not even a simple reproduction of population is possible (ibid.: 194).

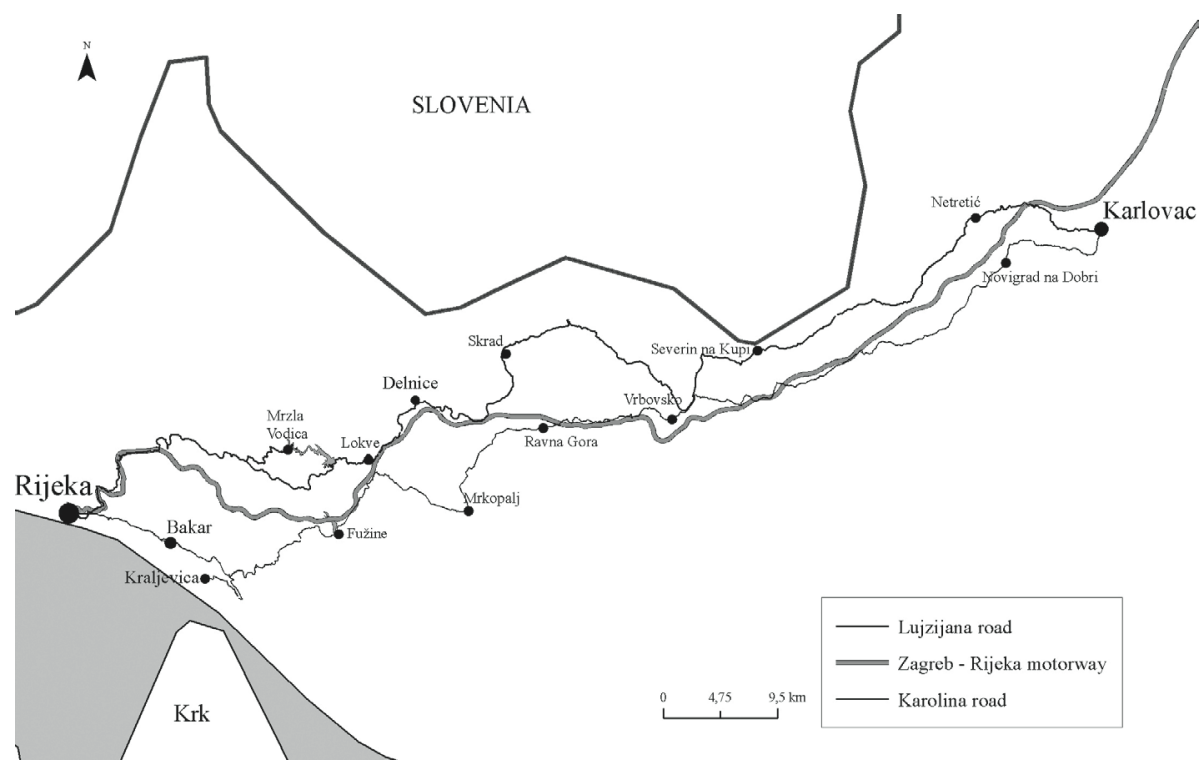

Picture 2. Map showing the Karolina road, the Lujzijana road and the Zagreb-Rijeka motorway (made by geographer Klara Horvat for this publication)

Considering the economic exploitation of the region, the most important economic sectors are forestry and wood industry (Lukić et al. 2009: 158). The service industry used to be largely determined and defined by the roads - catering services and small shops in

${ }^{5}$ Towns: Čabar, Delnice and Vrbovsko; municipalities: Brod Moravice, Fužine, Lokve, Mrkopalj, Ravna Gora and Skrad.

${ }^{6}$ According to the 2011 census, there were 18 inhabitants per square km in Gorski Kotar (population density in the same year in Croatia was 75.8 inhabitants per square km) (www.dzs.hr, accessed 17 October 2019).

7 In 1890 Gorski Kotar had 48,484 inhabitants (Knežević and Grbac Žiković 2013: 117) and in 23,011 inhabitants in 2011 (www.dzs.hr, accessed 28 October 2015). 
the settlements along the roads (ibid.). Throughout history, the region has had a key transit importance: rail routes, roads, and now the motorway, connect continental Croatia and Central Europe with the Croatian coast. The first roads through Gorski Kotar were built already in the Roman times. Before the construction of the first "modern" roads, trading transit took place through caravan paths (Černicki and Forenbaher 2012: 11). Changes in trading and road building occurred in the early $18^{\text {th }}$ century when the Karolina road (from town of Karlovac to the towns of Bakar and Rijeka) was built, as ordered by Charles VI, a Habsburg monarch. ${ }^{8}$ Being the first modern road in Gorski Kotar, connecting continental Croatia with its seaside, the Karolina road represented significant progress in the traffic of the region. However, with its frequent steep rises and sharp turns, it did not serve all the needs of trade and transit after all. In the second half of the $18^{\text {th }}$ century, there emerged a need for a new road from Karlovac to Rijeka, a road that would have a more favourable trajectory. The construction of the new road started in 1803 under the governance of the Austrian Empire and was finished in 1811, in the period of French rule (Glad 2014: 37). It was situated north of the Karolina road and was called the Lujzijana road. ${ }^{9}$ It was reconstructed, renovated and modernized over the years to suit the needs of modern transit. Road traffic varied over the century: it decreased at the end of the $19^{\text {th }}$ century due to a new railway route (in 1873) between the towns of Karlovac and Rijeka, it increased after World War II and then decreased again after the construction of the Zagreb - Rijeka motorway. Even though work on motorway construction began as early as 1970, while Croatia was part of the Socialist Federal Republic of Yugoslavia, work was resumed only after the Croatian War of Independence, ${ }^{10}$ in 1996 (Glad 2014: 138). By the year 2004, the cities of Rijeka and Zagreb were connected by a single route of motorway and semi-motorway and the road was completed in full profile and officially opened in 2008 (Glad 2014: 138-140).

The other infrastructure of interest, the dam, was built between the villages of Lokve and Mrzla Vodica in the period of 1952-1955. With the construction of the dam, a vast lake was created as part of the Vinodol Hydroelectric Power Plant, which flooded settlements of Srednji Jarak and Homer and part of the Lujzijana road (Bajzek 2002: 56). The dam, 48 meters high, was built by 27,000 youths from all parts of Yugoslavia and some from abroad as a part of, the so-called Omladinske radne akcije [Youth Work Actions], ${ }^{11}$

\footnotetext{
${ }^{8}$ The Karolina road was named after its founder, Charles VI (in Croatian, Karlo IV) (Černicki and Forenbaher 2012: 13).

${ }^{9}$ The Lujzijana road was named after the third wife of the Austrian emperor Francis I, Maria Ludovika. Because it was finished during the period of French rule, Lujzijana is wrongly considered to be named after Napoleon's second wife, Maria Louise, who was also Francis I's daughter (Feletar 2016: 149). In its original trajectory, it was 18 Austrian postal miles long (approximately 134 kilometres) (Černicki and Forenbaher 2012: 27).

10 1991-1995.

${ }^{11}$ Omladinske radne akcije were organized voluntary labour activities of young people in the Socialist Federal Republic of Yugoslavia. They were used to build public infrastructure such as roads, railways, and public buildings, as well as industrial infrastructure. Omladinske radne akcije were organized on the local, republic and federal level by the Savez komunističke omladine Jugoslavije [Young Communist League of Yugoslavia], and participants were organized into Omladinske radne brigade [Youth Work Brigades]. This complex social phenomenon is critically discussed in Senjković 2016. The author uses various forms of nar-
} 
which is why the lake was also called Omladinsko jezero [Youth lake] (Glad 1997: 27-29).12 Simultaneously with the building of the dam and because of the flooding of the part of Lujzijana road, south of the lake a new road, sometimes referred to as Nova Lujzijana (New Lujzijana Road], was constructed also by youth participating in Omladinske radne akcije.

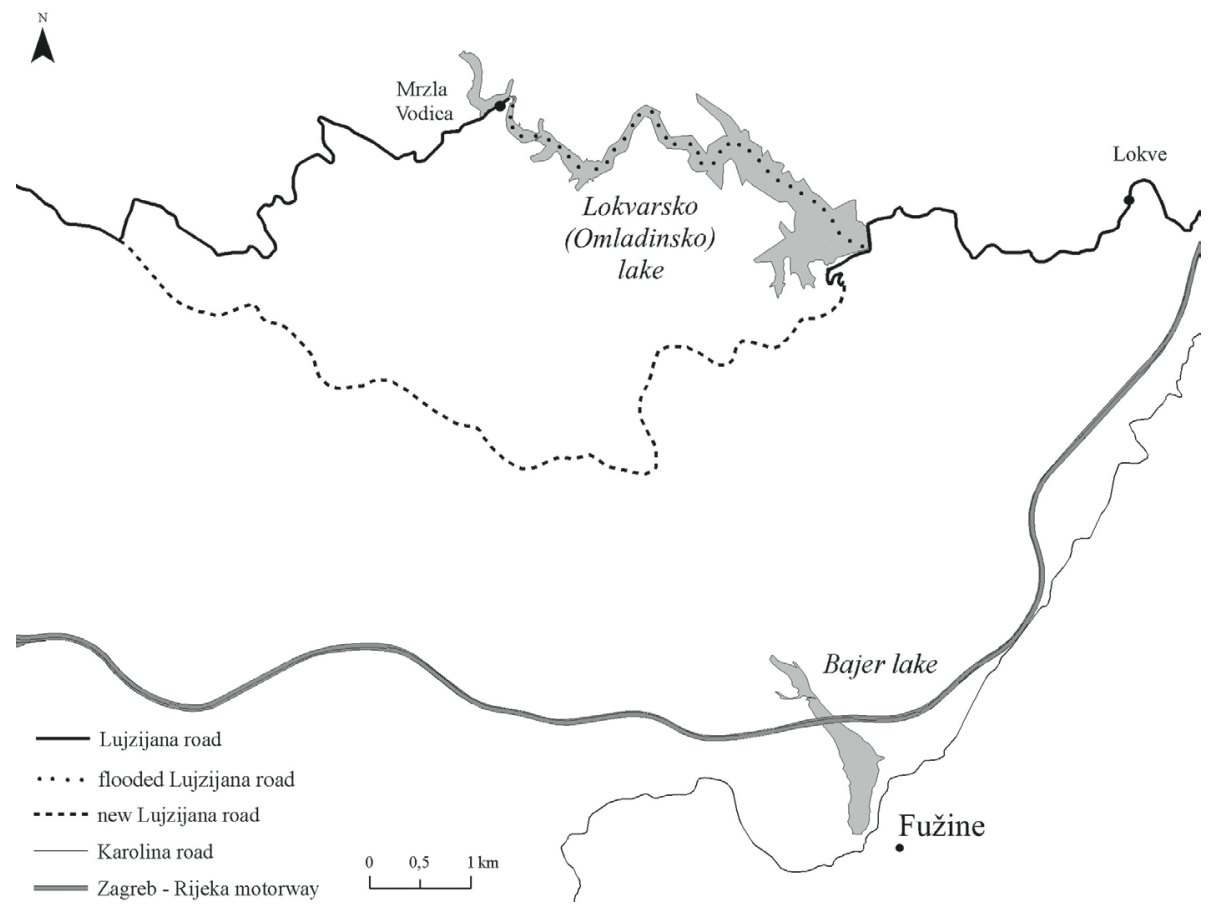

Picture 3. Map showing the section of the Lujzijana road flooded by the lake and Nova Lujzijana (made by geographer Klara Horvat for this publication)

\section{AFFECT, PLACE-MAKING AND INFRASTRUCTURE}

The concept of affect with its theories and methodology as a response to new interests and tendencies in contemporary studies in the social sciences and humanities started to form in the mid-1990s (for example, in literary studies, the focus shifts from textual interpretation to readers' affective responses (Frykman and Povrzanović Frykman 2016: 12)).13 The theory of affect brought attention to both body and emotions, but also to its

\footnotetext{
ratives as a source for interpretation, thus showing a multiplicity of voices of this phenomenon of Yugoslavian socialism that is still present today in the form of nostalgia.

12 The first official name of the lake was Omladinsko jezero but it was later renamed Lokvarsko jezero. However, the local population still referrs to it by its former name.

13 The background and evolution of the theory of affect in the social sciences and humanities and its usage and methods in ethnology and cultural anthropology are given in Škrbić Alempijević et al. 2016.
} 
synthesis. Affect is the intensity that one experiences in a social context in relation to another person, group, being, thing, phenomenon or concept that can be expressed by activity or practice (Stewart as cited in Škrbić Alempijević et al. 2016: 65). The important characteristic of affect is that it is based on interaction and a process, that "enable(s) us both with power to affect the world around us and our power to be affected by it, along with the relationship between these two powers" (Hardt 2007: xii). Before the so-called "affective turn", many studies set to explore emotions in different social contexts were published without referring to the concept of affect per se. In comparison to studying emotions in a certain space, which enables the examination of place-making through linguistic labelling and consciousness of the individual, studying affect offers more flexibility in thinking how feeling makes a place, how feeling affects, circulates and infects more than one person (Low 2017: 145). So, the study of emotion in relation to the built environment, focuses more on individual rather than on collective experiences. Affect, on the other hand, opens a question of how the material environment transmits feeling. Both concepts of emotion and affect are components of place-making - with emotional and affective relationships towards the material environment, people form meaningful relationships, attaching or inscribing meanings to space, and transforming "space" into "place" (Low and LawrenceZúñiga 2003: 13). These relationships are also studied through the concepts of place identity, place bonds, affective attachment, place attachment, sense of place, topophilia, community attachment and local sentiment (Low 2017: 26; Cross 2001), concepts that tend to focus on the person, rather than on place characteristics. Focusing on affect that resides in the materiality of the place, with contextualization and historization, produces a nuanced interpretation of how a certain place is created and understood.

Studying infrastructure socioculturally presents a relative novelty in cultural anthropology. It started in the 1990s (e.g. Masquelier 1992, Roseman 1996) by examining a variety of infrastructural influences. Infrastructure is generally defined as "the basic, underlying framework or features of a system, as the military installations, communication and transport facilities of a country" (Webster's Dictionary 1996: 731). Anthropologist Brian Larkin defines infrastructure as "built networks that facilitate the flow of goods, people, or ideas and allow for their exchange over space" (2013: 328). Sociologist and urbanist AbdouMaliq Simone showed that infrastructure can also be examined as incomplete, selfmade or entirely absent (Simone 2003). Studying infrastructure anthropologically means focusing on the non-technological elements in it. Recent studies analyzed infrastructure as a concept, as well as specific infrastructure like roads, dams, railways, communication networks and pipelines, and showed a variety of dynamic ways that it can be explored: drawing on biopolitics, science and technology studies, theories of technopolitics, but also dimensions that release different meanings and structure politics through the aesthetic and the sensorial, desire and promise (Larkin 2013: 327). ${ }^{14}$ One of the first publications that dealt with the methodological problems of studying infrastructure is Susan Star's Ethnography of Infrastructure (1999) where she tried to define infrastructure and listed

${ }^{14}$ Brian Larkin (2013) provides a review of anthropological literature that theorizes infrastructure. 
its properties with this end. Star asserted that infrastructure is a relational concept that becomes real in relation to organized practice, that it is by definition invisible and one of its properties is that it becomes visible upon breakdown (Star 1999: 380, 382). An example of such an assumption is a closed road or a bridge because of the snow or wind, or power blackout - even though there might be back up mechanisms, people's routines have to be reorganized. Although invisibility can represent one aspect of infrastructure, this article provides examples that argue against Star's belief that infrastructure is invisible. By registering many mediated socio-material relations and communications, it becomes clear that infrastructure has different meanings for different people. Infrastructure coalesces with its natural surrounding and community, becomes imbued with meanings and is turned into a symbolic place, far from being invisible.

Even though studies dealing with the relationship between affect and space are sparse in ethnography, especially when it comes to infrastructural spaces, anthropologists did recognize feelings, atmosphere and reactions to be part of the creation of those spaces. In this short overview, two studies will serve as an illustration of this trend. In Masquelier's research in postcolonial Niger (2002) a profound ambivalence of Hausaphone Mawri towards the Route Nationale 1 is explored, expressed by their attitudes and stories they share. The author showed the fears of the older generations associated with evil spirits that dwell on the road as imaginative practices through which people read the landscape - in contrast to the younger generation's notion of the road as modernity's promise for a more rewarding life. Another study is by Clara Saraiva (2003), where she documents the most important events in the lives of the people of the village of Luz in Portugal, at the time when their village was moved to another location because of the construction of the dam of Alqueva in 2002. Flooding of the village and moving to the new location was a difficult period for the people of Luz, marked with fear, pain and sadness, but also a perspective for a new start, for some. Saraiva's description of various scenes and people's actions, like closing the door of the "old" house for the last time, keeping its keys, practices associated with moving the cemetery to a new location, the last celebration in the old village, changes in people's lifestyles and routines while they were getting accustomed to the new spatial organization of the new village, shows how, through collective solidarity, the community was preserved, even though it had to re-make the "soul" of their new village.

\section{AFFECT IN INFRASTRUCTURAL SPACES IN GORSKI KOTAR}

The Lujzijana road, dating to the beginning of the $19^{\text {th }}$ century, is considered to be an initiator of prosperity and progress of Gorski Kotar. At the time, the new road spurred the creation of new settlements, demographic growth ${ }^{15}$ and development of new economic activities, especially engaging in businesses related to transport and travel - road stations, cargo transport, lodging establishments and taverns. The Lujzijana road lost its transit

${ }^{15}$ For example, the village of Lokve in 1805 had 481 inhabitants (Glad 1997: 9) and in the year 1857, 2,070 inhabitants (Feletar 2016: 212). 
value when the Zagreb - Rijeka motorway was constructed in full length in 2004. The new circumstances particularly affected the economy by the road: small businesses and services closed down and transit tourism started to decrease. Because of the notion of the Lujzijana road as an initiator of progress but also because of its significant construction characteristics, today, more than 200 years later, the Lujzijana road is considered a cultural heritage. In the last decade, local associations and enthusiasts have been striving to revive tourism in Gorski Kotar by organizing their efforts in different activities to build a tourism product and attract funding and tourists. In 2015 in Lokve, I had the opportunity to take part in one such activity, a tour organized by a local association. The tour was intended for other local organizations and individuals with existing tourism products or services as well as others, enthusiasts, who were simply interested in participating in the tour. The aim was to familiarize the local community with the existing tourism offerings and discuss its possibilities for the future, organized around the Lujzijana road as a tourism product and physical cultural route. The tour with approximately 25 participants, in addition to other activities, visited the most important Lujzijana road sites and the lake. Besides looking to realize economic profit, improve the tourism sector on the local level or create new jobs, this practice also meant mapping respect and love for their heritage, including infrastructure. At each location of the tour, different people would talk to the group about the Lujzijana road and the lake, their history, technical specifications and anecdotes. As the atmosphere of the tour was informal, many nostalgic memories, romantic and poetic descriptions of the Lujzijana road, the dam and the lake emerged. One of the participants in the tour was Matija Glad, PhD, a traffic engineer. He was invited to talk about Lujzijana's technical specifications but also because of his well-known enthusiasm for historical roads in Gorski Kotar. Even though his primary research interest was public road maintenance, he also published several articles about historical roads in Gorski Kotar and a book including the history of roads in the Primorsko-Goranska County. He started his speech with the following words: "I was born in Belo Selo located on Karolina, but I like Lujzijana more, I don't know why". One would think that in the eyes of engineers, the Lujzijana road is an infrastructural project where only numbers and figures matter, but he recited the poem Cuvajte me [Cherish me], noted at the beginning of this article. The poem gives voice to the Lujzijana road, which talks about how it should be taken care of. It is an emotional poem about how a materiality such as a road has been changed through time and what should be done with it in the future. He complemented the poem by saying:

With this poem I wanted to encourage myself and others to protect and cherish our heritage because it is valuable, we must show it and talk about it. It is unreservedly of use to us, because Lujzijana was one of the most beautiful, one of the highest quality and one of the best roads in all of the Austrian Empire. We have something to brag about.

The audience gave a most enthusiastic applause at the end, shouting "Bravo!". Later, when he talked about specific methods of construction or historical anecdotes, comments from the audience could be heard, including "astonishing", "unbelievable" or someone would just exclaim "wow". Later in his speech, he also admitted to the group that something was still troubling him, even after 39 years: as a young engineer, in the 1970s, he was ordered 
to demolish a church by the lake because the water level threatened to increase. He was visibly upset and said that he still feels bad and guilty about it. However, the water level never increased to that point. The group reacted compassionately, sharing his grief and sorrow for the lost church.

There are also several published poems about the Lujzijana road. A poem by definition expresses feelings and ideas the author is passionate about. They were all written by locals: Lujzijana $v$ asfalte [Lujzijana to be paved] and Brige oko ceste [Worries about the road] by Đurđica Asić Klobučar (2002) - written in the local dialect - and the folk poem Lujzijanka (Laloš 2007). The first of these retells a dialog between two old ladies. It refers to the time of modernization of the Lujzijana road. The poem talks about the exciting news of paving the road, speculations about what asphalt actually is and whether there would be some adjustments or bypassing. At the end, one lady asks whether she would live to see the new road. The second poem by Đurđica Asić Klobučar refers to the time before the opening of the motorway and looking forward to it. It talks about the overwhelming number of trucks on the Lujzijana road during the week and luxury cars during the weekend. The traffic prevents locals from going about their everyday routine, like going to church, because they cannot cross the road. The poem expresses the hopes of the locals and promises of the motorway which will "put an end to their fears". Even though the two poems refer to different roads as novel elements, both of them convey feelings of excitement related to infrastructure: modernization of the Lujzijana road and the motorway as an answer to people's worries. New infrastructure is typically marked with notions of progress even though outcomes can turn out to be different from the expectations. Whether it is excitement, hope or fear, those novel and alien elements serve as an inspiration to poetic reactions by those who attempt to make sense of them. As Dalakoglou puts it: "It is impossible for infrastructure such as new roads to be introduced into the space and life of a community without causing major socio-cultural transformations, which are then reflected in local narratives" (2017: 93).

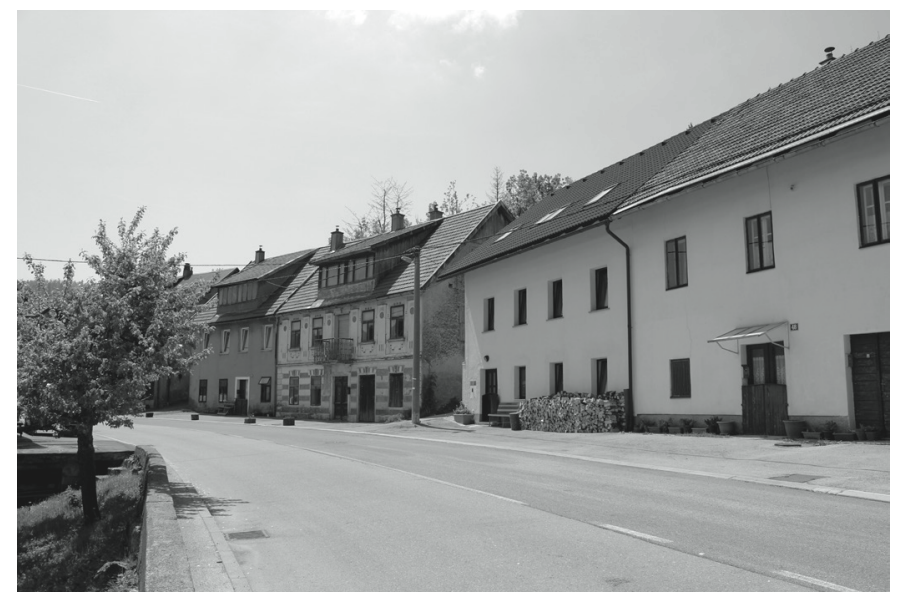

Picture 4. The Lujzijana road passing through Lokve (photograph taken by Morana Jarec on 17 May 2015) 


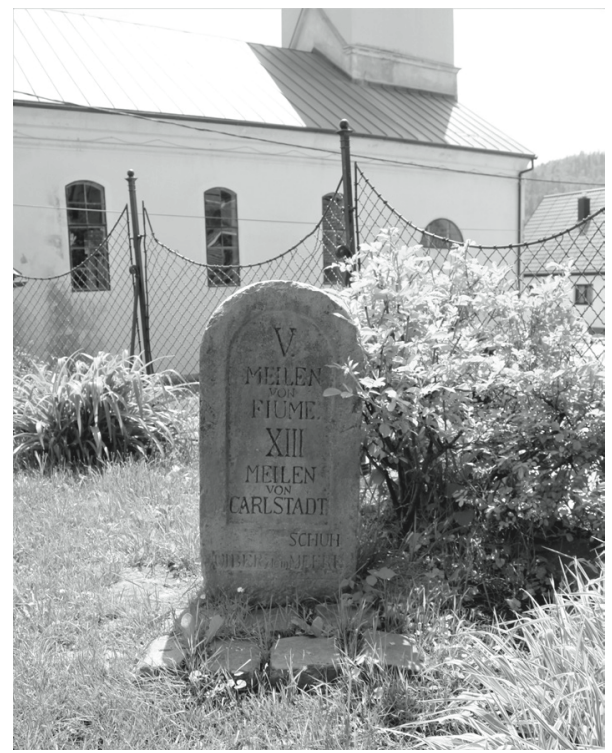

Picture 5. A milestone, miljokaz, in Lokve, indicating the distance in Austrian postal miles to the cities of Rijeka and Karlovac and the elevation of the location (photograph taken by Morana Jarec on 17 May 2015)

The folk poem entitled Lujzijanka, which can be understood as an endearment variant of the road's name, is about the Lujzijana road's trajectory and impact on demography and prosperity. The poem ends with the verse "(she) opened paths to people for eternity" (Laloš 2007: 75). Here, the Lujzijana road represents a metaphor for new opportunities created by the road, which can be interpreted in many ways: from its impact on demography, mobility, economy or simply referring to encountering travellers. For Mikhail Bakhtin, a road is a chronotope upon which representatives of all social classes, estates, religions, nationalities and ages intersect in one spatial and temporal point; it is a good place for random encounters where the most divergent fates may collide and interweave with one another and where social
road thus becomes the source of "rich distances may collapse (1982: 243-244). The road thus becomes the source of "rich
metaphorical expansion on the image of the road as a course" (ibid.: 244). In addition to Lujzijana being an inspiration for poetry with the road as its main motif, Lujzijana's great impact on people's lives is evident in the fact that Lujzijanka was put to music and played at weddings (Laloš 2007: 74-75).

A literary example showing a strong connection to the Lujzijana road can be read from Rudolf Strohal's travel diary. ${ }^{16}$ Strohal wrote Uz Lujzinsku cestu [By the Lujzijana road] (1993 [1935]) describing the road, environment, history and the settlements from Rijeka to Karlovac with great passion, giving many facts and incorporating his impressions and thoughts. In the first chapter, he wrote: "Inhabitants that inhabited the Lujzijana road from Rijeka to Karlovac, felt like one big municipality, like one community" (Strohal 1993 [1935]: 23). This work is also valuable because, as it was written in the 1930s, it incorporates the section of the road (Mrzla Vodica - Lokve) that was flooded in the 1950s. It also shows the emotive atmosphere on the road at that time, for example that it was dangerous to

${ }^{16}$ Rudolf Strohal (Lokve, 5 April 1856 - Zagreb, 21 March 1936) was a Croatian linguist and historian. Although he only lived in Lokve until the age of 9, Strohal was strongly dedicated to his home region. That is visible in his professional life: he studied the dialects of Gorski Kotar, collected and published folk stories in the dialects of Gorski Kotar, studied local histories by collecting records of folk customs, immigration, families and family names. Also, his father participated in the construction of the Lujzijana road as the main engineer and head of the Lokve section. 
travel by night, because of many robbery attacks. ${ }^{17}$ The book was clearly frequently read by the locals and it is interesting how some portions of the book were paraphrased in the interviews. Specifically, it refers to descriptions of forests between Lokve and Delnice where robbers used to hide and attack rich traders or just plain travellers. They would also break into houses and even torture and kill people. One of my interlocutors said:

Do not think that all was great on the Lujzijana road. If rich traders would spend the night in one of the lodges by the road, robbers would break in, they even cut off a hand of a tavern owner in Kupjak:18

which is exactly what Strohal writes about in the 1930s (1993: 71). In these stories, scenes of insecure daily life emerge, although not from personal experience but from the distant past, even legends.

In conversations with people, I was interested in registering how affects are narrativized - how people speak of the road, the dam and the lake, and what it reveals about their relationship with it. When I asked which road they take when travelling to Rijeka, one of my interlocutors said enthusiastically:

We take the Lujzijana. We take nothing but the Lujzijana. We take nothing but the Lujzijana. No traffic. Great. And an excellent road. I know it by heart. With my eyes closed.

There were expressions like "I was born on it, I learnt how to walk and speak on the Lujzijana road", and "a road without flaws". When speaking about the Lujzijana road, people use its name and often speak of it as if it were a person, a female. ${ }^{19}$ Some of the examples are: "she is a beauty", "she climbs wisely, rests, then veers winding", speaking of the road's trajectory, and "she immerses into the lake", speaking of the part of the road flooded by the lake. For one of my interlocutors, the dam and the lake had life-changing meanings. Her personal story, career and connection to the dam and the lake is one of a kind. This is evident in the excitement when she talks about her family history; the progress that was supposed to be brought by the dam and the lake as part of the landscape; but also in her changed lifestyle and practices. Her father who came from another city to work on the construction of the dam, met her mother who was from a nearby village, so she says that "if it wasn't the dam, I wouldn't be here!". As for the choice of her profession, she says:

Then I went to Rijeka to study civil engineering. And right away I choose hydrotechnics, that programme, because, for me, water and all of this, this is natural for me, I guess, I was born on the water, everything is connected to water for me. And I really love my job.

${ }^{17}$ Strohal calls these robbers hajduci (hajduk sg; hajduci pl), a term used for bandits in South-Eastern Europe under the Ottoman Empire.

${ }^{18}$ Kupjak is a village located on the Lujzijana road.

${ }^{19}$ One reason for this is also the fact that the Croatian word for road, cesta, is of feminine gender. 
Even though she was born there, the whole family soon moved to the city of Rijeka. Recently, she moved back with her husband, simply because "it's beautiful", and still travels everyday back to Rijeka for work, on the Lujzijana road. ${ }^{20}$

Unlike the case of the village of Luz in Portugal where the village was moved to another location because of the construction of the dam of Alqueva (Saraiva 2003), several villages in Gorski Kotar had a different fate. The dam in Lokve was built in the 1950s flooding not only houses and roads, but also making a community disperse. However, the local people that worked on the construction of the dam, as participants in Omladinske radne akcije, remember this part of their lives as joyous and happy, a time when they got to know many young people from all over Yugoslavia and from abroad. I learned from the interviews transcribed in Lokvarski zbornik that they did not care about peoples' places of origin, what religion they were, in line with the popular slogan of the time - bratstvo $i$ jedinstvo [brotherhood and unity]. ${ }^{21}$ They did not mind the eight-hour hard work days and some of them were even underage. With 27,000 young people in total working on the construction site in the period from 1952 to 1955 (Pleše 2004: 29), there was a temporary "city" constructed for accommodations and common rooms, which also contributed to the good memories of having fun with their new friends. Some locals, describing that period, said "the most beautiful days of my life" and "we were constantly singing and I was happiest when my brigade would do well and got a citation for it".

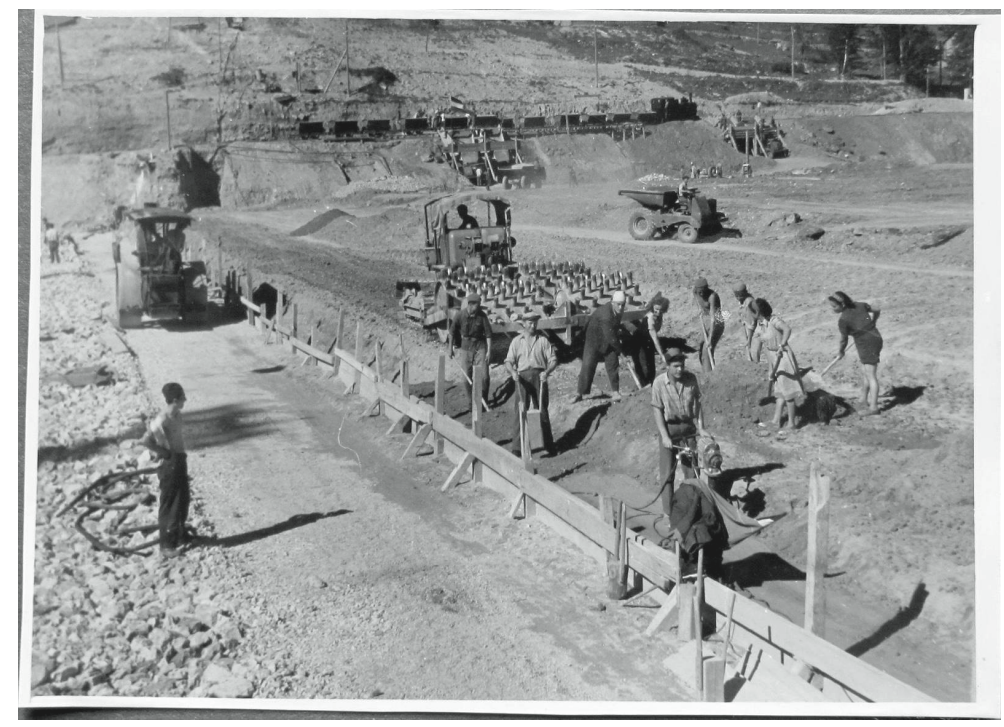

Picture 6. Photograph taken during construction of the dam in Lokve in 1953

(http://croinfo.net/forum/index.php?topic=2955.15, accessed 2 April 2019)

\footnotetext{
${ }^{20}$ Approximately 40 kilometers or half an hour by car.

${ }^{21}$ Bratstvo i jedinstvo was a popular slogan of the communist party of Yugoslavia that was coined during the Yugoslav People's Liberation War (1941-45), and which evolved into a guiding principle of Yugoslavia's post-war inter-ethnic policy (Mesić 2004: 246).
} 


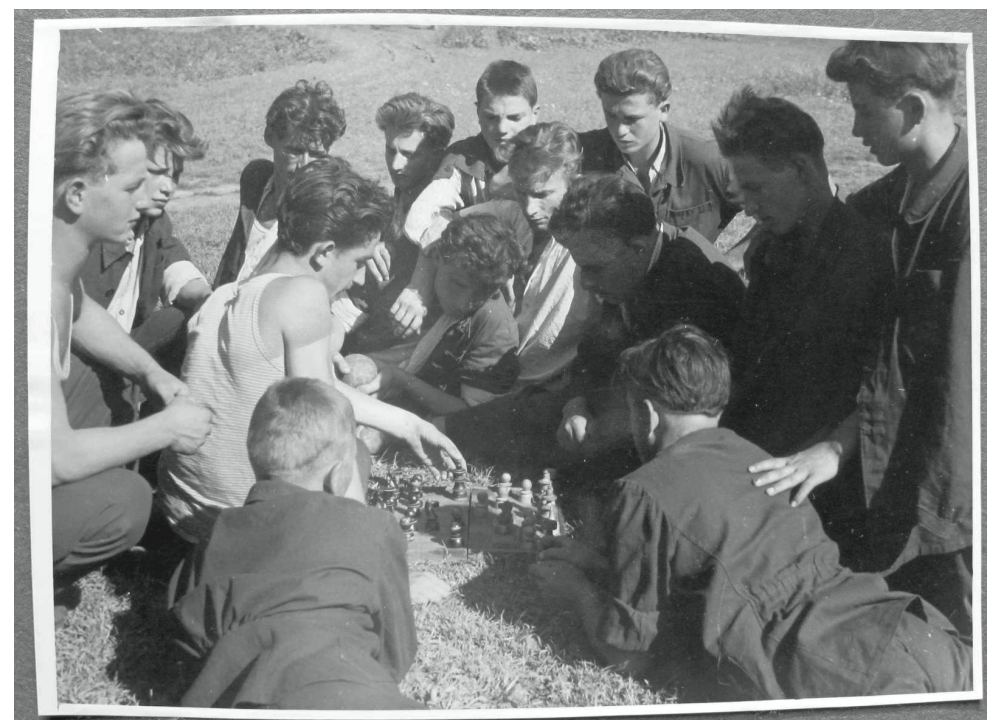

Picture 7. Members of Omladinske radne brigade [Youth Work Brigades] spent their free time in organized activities such as chess competitions, football and volleyball matches, track running, reading, conferences, military education etc. Photograph taken in 1953 (http://croinfo.net/forum/index.php?topic=2955, accessed 2 April 2019)

There is also a poem about the construction of the dam, written by Nikola Culinović. The poem has not been published, it was given to me during one of the interviews in Mrzla Vodica. Nikola, as a young engineer from Zagreb, was appointed to the construction of the dam. The poem is entitled "Život za život" [Life for life], and it was written 25 years after the construction of the dam, remembering a student from Belgrade, a member of Omladinske radne akcije, who lost her life on the construction site. The other "life" in the title refers to the meaning of the project of the construction of the dam to the people of Gorski Kotar - the electric energy to be produced by the hydroelectric power plant, which meant progress and modernization of Yugoslavia and, thus, life. We should not ignore the propaganda of the Republic of Yugoslavia at that time or the political heritage of the region. When Mussolini's fascist Italy annexed parts of the Croatian territory in 1941, the border passed through the village of Homer (Komadina 2015: 14), leaving Mrzla Vodica and Srednji Jarak in the Italian territory, and Lokve in the territory of the Nezavisna država Hrvatska - NDH [Independent State of Croatia], a newly established, also fascist, puppet state. Considering the new political organization in this small area, people of Gorski Kotar had to fight against the Italian army perceived as occupiers and were directly exposed to the events of World War II. In that regard, they welcomed the liberating partisan forces that subsequently lead to the establishment of the Federativna Narodna Republika Jugoslavija [Federal People's Republic of Yugoslavia] (Socijalistička Federativna Republika Jugoslavija [Socialist Federal Republic of Yugoslavia] from 1963 onward). With this kind of intertwining of ideology and affect, political and spatial projects operate on both the affective and the ideological level (Low 2017: 153). 


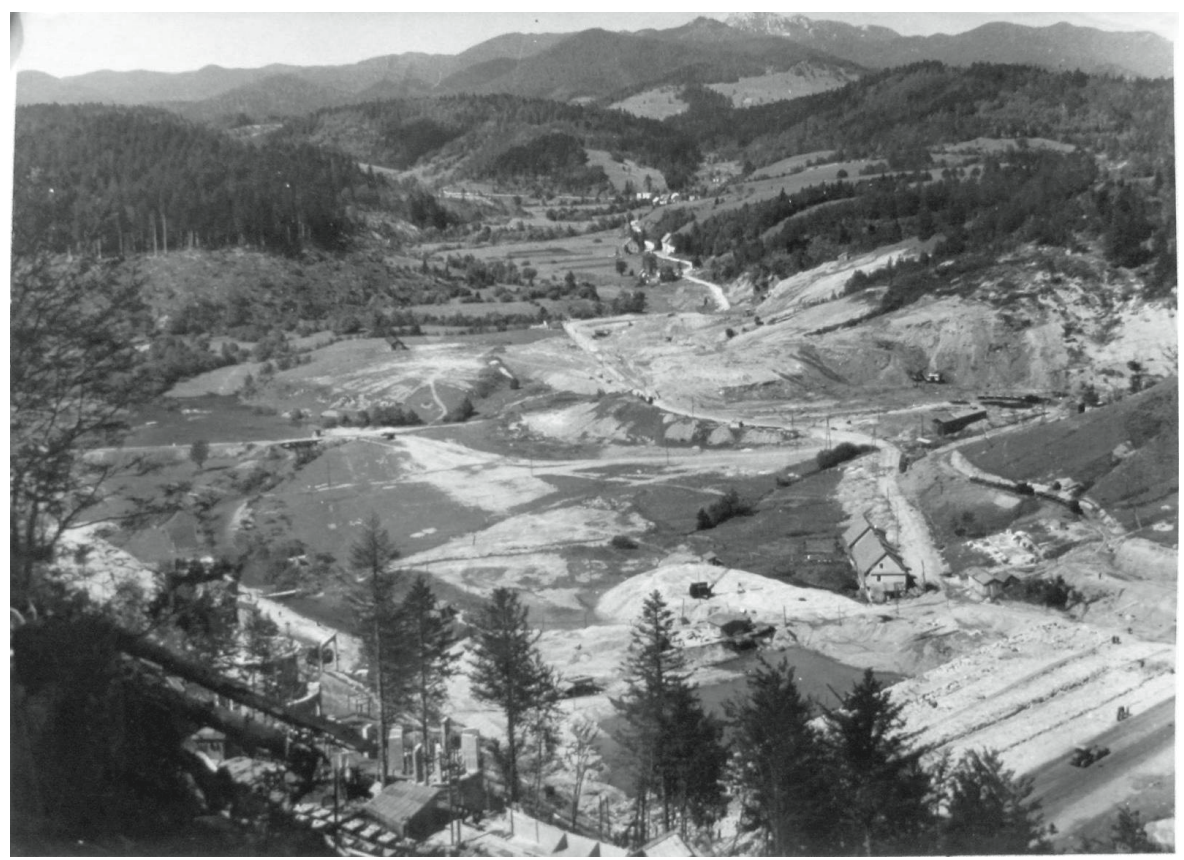

Picture 8. Space of the future lake; photograph taken during construction of the dam in Lokve, in 1953. (http://croinfo.net/forum/index.php?topic=2955.0, accessed 2 April 2019)

While the period of the construction of the dam is marked by positive memories, compassion for those who died during the construction and the idea of progress to be brought by the project of the dam, the other part of the infrastructure, the lake, triggers sadness and nostalgia for the lost villages. Memories of the lost villages are cherished and new generations are encouraged to do the same. In 2001, the lake was drained because of maintenance work on the control and protection of the plant. It was a unique opportunity to walk on the lake bottom. Mirjana Pleše, a school teacher from Lokve, was one of the main organizers of the walk on the lake bottom. I learned from her that eight kilometres of the Lujzijana road, two bridges, sixty-nine houses, six sawmills, a chapel, an inn and a bakery were flooded by the lake. The organized walk included documentation of ruins, trajectories of the Lujzijana road and streams, as well as documentation of memories of people that used to live there. Ruins of houses, the Lujzijana road, bridges, streams, even trees could be seen and people would talk about what they remember about the life before the lake. By moving through the lake bottom, it becomes an embodied space where human experience and consciousness took on material and spatial form (Low 2009: 28). One of participants in the walk said:

I walked the lake bottom and felt that my whole body was trembling from grief and memories of childhood that I spent there in our house and our sawmill with my family.

(Pleše 2004: 31) 
Others talked about what they remembered about the villages, whether about the buildings that once stood there or events from their life there. Here, affect is produced through ruins as an ethnographic means for understanding spatial melancholy and evoking nostalgia for past histories (Low 2017: 153).

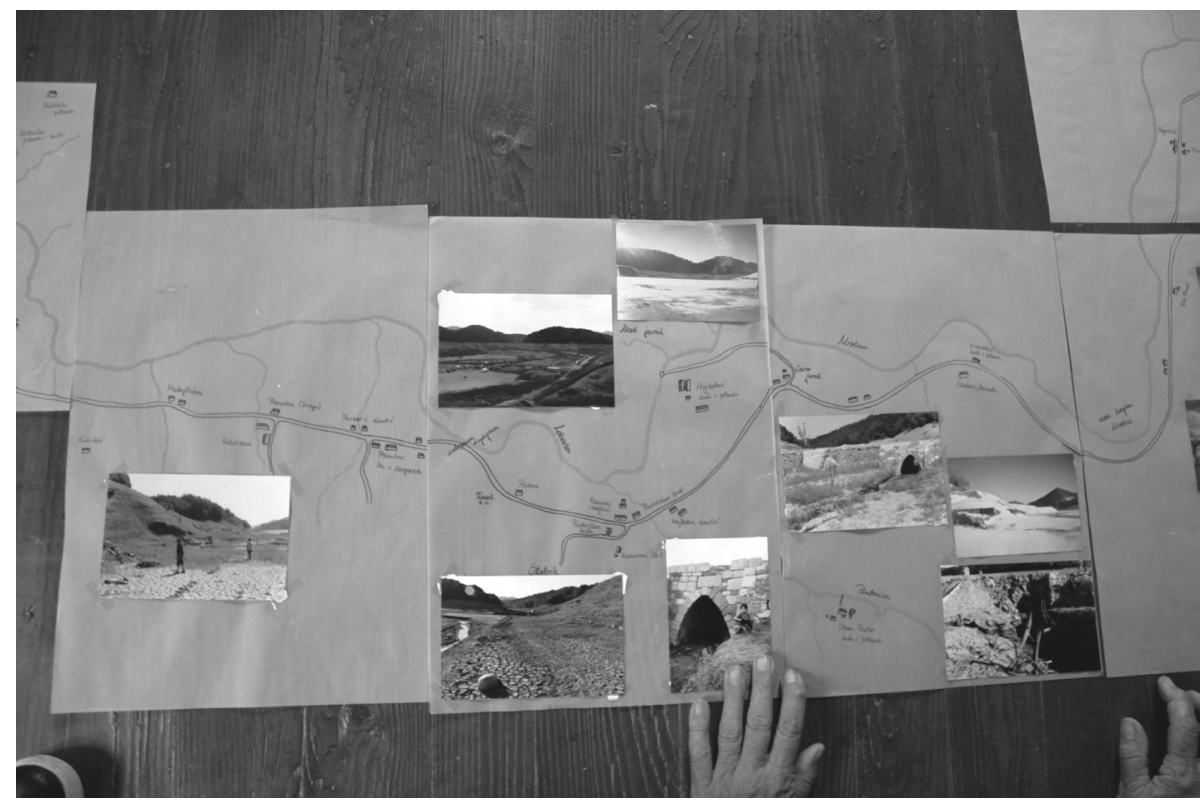

Picture 9. Mirjana Pleše shows photographs and a map of the bottom of the drained lake with documented locations of family houses, sawmills, bridges, road and stream routes (photograph taken by Morana Jarec on 21 May 2015)

Mirjana Pleše, the main organizer of this event, said:

Love for the flooded part of Lokve, that I felt in the memories of people that taught me about that time, committed me to further efforts to save it from oblivion.

Continuing to transmit those affects as part of the collective memory, in 2002 in Lokve, she organized an exhibition devoted to the construction of the dam, with photographs of the flooded villages and a ground plan including the list of sawmills and families that used to live there. She also encouraged school children (age 12-14) to use the drained lake as a source of inspiration for poems and short stories about their own experiences of walking on the lake bottom and their emotions, and to interview people who used to live there, those who remember the villages before the dam was built and participants in Omladinske radne akcije. School children, as contemporaries of the drained lake, had an opportunity to see the road, the streams and the bridge which were under water for 50 years, touch the ruins and imagine what it was like back then, learning about their heritage and history. Some of them are cited here and can be found in Lokvarski zbornik (Pleše 2004: 40-44): 
While I was looking at Lujzijana, I got an impression that I was watching a movie; I am happy for the unique opportunity to see what was left and imagine what their houses and the sawmill looked like;

I can imagine myself in their house;

One thing is for sure: I will remember it forever;

I couldn't see that beauty (referring to the bridge) earlier, not even my parents could;

...the bridge seemed alive;

...in spite of life, everything was sad, seemed abandoned and dead without people;

I greeted the pillars from the old fence, they survived time, misfortune, water, ice;

I'm sure the houses were beautiful, alive, full of people, that they lived by children's laughter;

I'm worried whether they had a difficult time abandoning their houses;

I tried to revive the houses using my imagination;

...if only the road could talk;

I could easily imagine how it had been when Lujzijana was still alive and young.

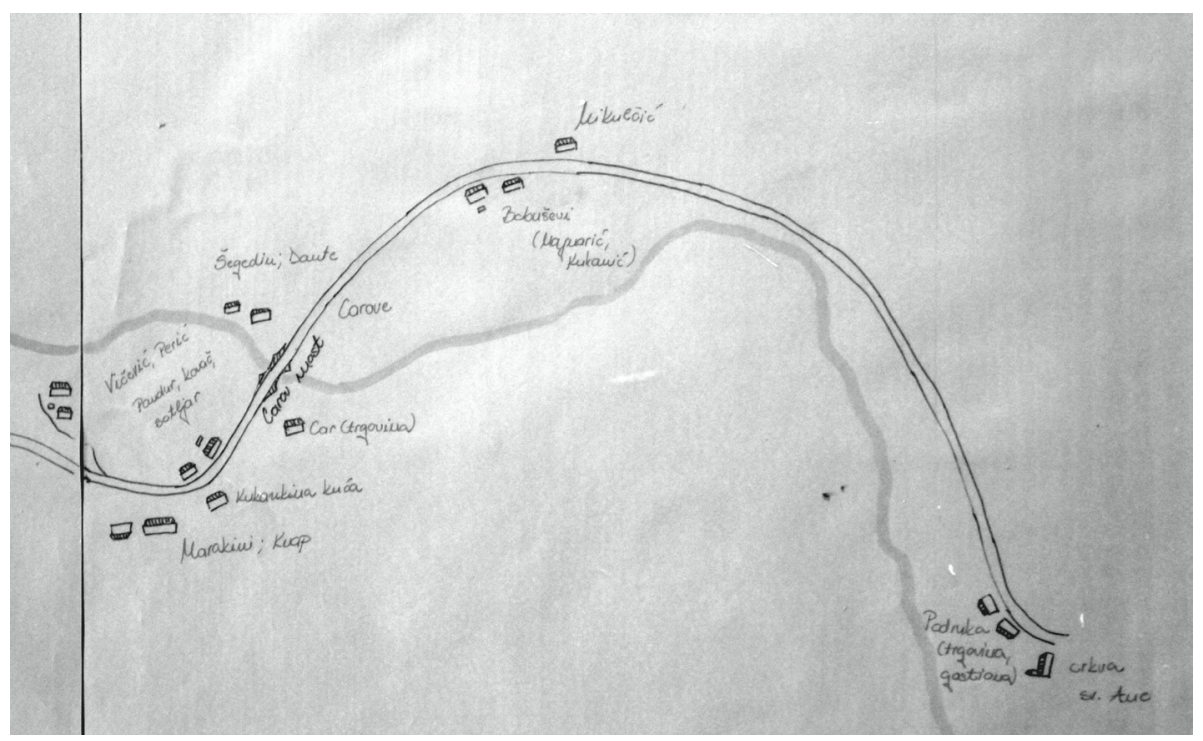

Picture 10. Ground plan of the part of the drained lake showing part of the Lujzijana road, and location of the Carov most bridge (photograph taken by Morana Jarec on 21 May 2015)

The project of the dam itself has somewhat ambivalent meanings for the locals. Some consider it a failed project that put an end to the development of Lokve and Mrzla Vodica and marked the point when people started to move out. Others say that the "loss of a few houses is insignificant to the importance of such a big project" and that "all of them would eventually move either way, just like the rest of Gorski Kotar". People also complain about microclimate changes it provoked: low temperatures and fog during most of the year. Even though the lake flooded the villages and people were forced to move out, my interlocutors who were contemporaries of that time, said that they did not remember that 
someone was particularly mad or sad about it. Even more so, people got properties closer to the seaside where they could get jobs more easily. How significant the construction of the whole complex was is evident in the fact that after the construction of the dam the production of electric energy in Croatia doubled in comparison to the previous five-year period. ${ }^{22}$ As one of my interlocutors said enthusiastically and continued to enumerate facts and figures about the production of electric energy at the time:

This marked the point of creation of our energetics! And of course, the beginning of the whole economic and cultural development of our country! It was all for our economic development, technological development, without electricity, you got nothing, everything would stop!

Another fact of significance is that the lake is integrated into the natural landscape as if it were not artificial. Thus, it represents a major tourism and sporting opportunity. Other than individual efforts, dreams and expectations, there is no formal plan of tourist exploitation of the lake on the political and professional level. Putting it into the context of the present poor demographic and economic situation in Gorski Kotar in general, those positive thoughts are often followed by an intense debate on political decisions on the local level, complaining that politicians are the ones who "systematically destroy the village".

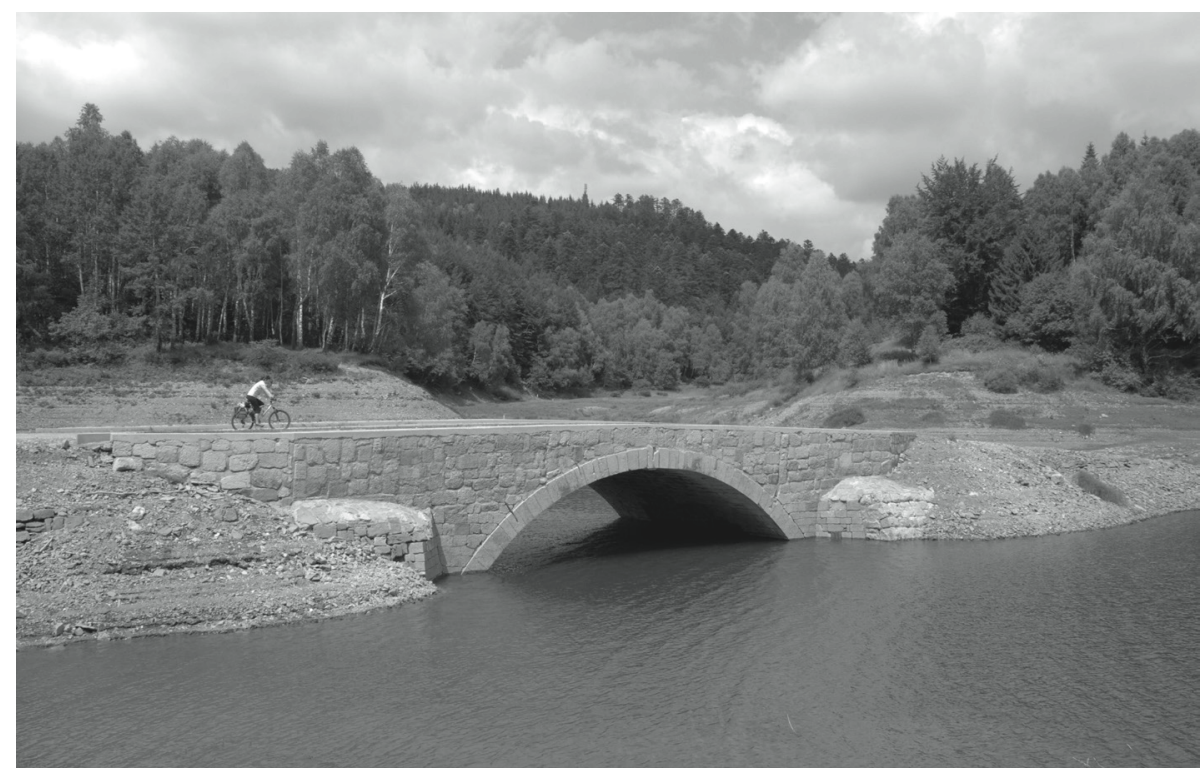

Picture 11. Renovated bridge on the part of the Lujzijana road flooded by the lake. The bridge, Carov most, is visible when the water level is low (Černicki and Forenbaher 2012: 160)

22 In 1950, 577 GWh of electric energy was produced in Croatia and 2,408 GWh in Yugoslavia; in 1955 1,021 GWh was produced in Croatia, and 4,339 GWh in Yugoslavia; and in 1960 1,671 GWh was produced in Croatia and 8,928 GWh in Yugoslavia (http://tehnika.lzmk.hr/tehnickaenciklopedija/elektroprivreda_i_elektroindustrija.pdf, accessed 15 October 2019). 


\section{CONCLUSION}

Relying on the anthropology of space and place, a theory of affect and in contrast to Star's assertion on infrastructure being invisible, this article shows that the Lujzijana road, the dam in Lokve and the artificial lake are spaces that are inextricably bound to the local community's everyday experiences and actions. People experience affects in relation to both physical features of these key pieces of infrastructure and their influences. They give meaning to people's experience and vice-versa: through people's emotions, opinions and actions as part of affects, these infrastructural spaces are interpreted, understood and (re) created, shifting boundaries between material and immaterial structures.

Both infrastructural constructions, the Lujzijana road and the dam with the lake, transformed the landscape and community life over the long term. In the period when they were constructed, they were both initiators or turning points of major events. In the case of the Lujzijana road, the settlements alongside the road were created because of it and new opportunities for different businesses emerged; and in the case of the dam, it was an element of progress which shaped not just the local level but the entire country; however it also meant that people had to move because of the flooding of the villages. The infrastructure and its effects are perceived, narrativized and experienced by the local population in different ways - they are expressed in literature and published, memorized, and performed; narrativized in plain conversations; expressed through both individual practice and organized activities, such as tourist tours, walks through the drained lake and documenting and exhibiting the findings. Published and performed literary work and organized activities transmit affect to others, triggering their affective responses. Individuals incorporate infrastructure as metaphors in their personal lives and identities - their lives started there: "I was born on it, I learnt how to walk and speak on the Lujzijana road" or "if it wasn't for the dam, I wouldn't be here!". Being 200 years old, a remarkable work of road construction, the local population perceives the Lujzijana road as a valuable cultural heritage. An attitude of respect and a certain atmosphere of mysticism can be read from people's narratives and practices - it is always referred to by its name; it is the centre of planned tourist activities; it triggers imagination on how it was "back then". The space of the dam and the lake, on the other hand, has twofold, ambivalent, meanings in several aspects: it is a space of a failed project in the migrational and ecological sense, in contrast to the expectation of the project that, as one of my interlocutors said, "marked the point of creation of our (Croatian) energetics"; it is a space of flooded heritage in contrast to the tourism opportunities gained by the vast lake; it is a space of joyous memories of the time of the construction in contrast to the feelings of nostalgia for the lost villages. Walking through the drained lake, documenting, exhibiting and encouraging children to use their imagination and write about it, are practices that are an attempt at bringing together those two diverse sets of affects: celebration of the good times and sadness for the lost heritage. 


\section{ACKNOWLEDGMENTS}

I would like to extend my gratitude to my friends in Lokve and Mrzla Vodica for their participation in this research. I sincerely thank my advisor, Professor Valentina Gulin Zrnić, PhD, for her inspiring guidance, encouragement and thoughtful comments on the earlier drafts of this article. I would also like to thank two anonymous reviewers for their constructive suggestions on how to improve the manuscript. I am very grateful for the guidance and assistance during fieldwork, selflessly provided by Ana Perinić Lewis, PhD. Finally, special thanks to Professor J. Marla Toyne, PhD, for proofreading the text and Klara Horvat, M. Ed., for making the maps.

\section{REFERENCES AND SOURCES}

Asić Klobučar, Đurđica. 2002. Zelene brige. [Green worries]. Kupjak, Zagreb: Dar usluge d.o.o.

Bajzek, Miroslav, ed. 2002. O postanku i sudbini naselja Mrzla Vodica. [On the origin and fortunes of the Mrzla Vodica settlement]. Rijeka, Mrzla Vodica: Društvo za očuvanje i razvoj naselja Mrzla Vodica.

Bakhtin, Mikhail M. 1982. "Forms of Time and the Chronotope in Novel". In The Dialogical Imagination. Michael Holquist, ed. Austin: University of Texas Press, 84-258.

Cross, Jennifer E. 2001. What is Sense of Place? $12^{\text {th }}$ Headwaters Conference, Western State College. Available at: https://www.researchgate.net/publication/282980896_What_is_Sense_of_Place (accessed 10 April 2019).

Černicki, Lara and Stašo Forenbaher. 2012. Starim cestama do mora [On the old roads to the sea]. Zagreb: Lubricon.

Dalakoglou, Dimitris. 2017. The Road. An Ethnography of (Im)Mobility, Space, and Cross-border Infrastructures in the Balkans. Manchester: Manchester University Press. https://doi.org/10.7228/ manchester/9781526109330.001.0001

Feletar, Petar. 2016. Hrvatske povijesne ceste. Karolina, Jozefina i Lujzijana [Croatian historical roads. Karolina, Jozefina and Lujzijana]. Zagreb, Samobor: Meridijani.

Frykman, Jonas and Maja Povrzanović Frykman 2016. "Affect and Material Culture. Perspectives and Strategies". In Sensitive Objects. Affect and Material Culture. Jonas Frykman and Maja Povrzanović Frykman, eds. Lund: Nordic Academic Press, 9-28. https://doi.org/10.21525/kriterium.6

Glad, Matija. 2014. Ceste Primorsko-goranske županije. Povijest cestovnog graditeljstva i održavanja. [Roads of the Primorsko-Goranska County. The history of road building and maintenance]. Rijeka, Kukuljanovo, Novi Vinodolski: Društvo za ceste VIA-VITA, Ceste Rijeka, Naklada Kvarner.

Glad, Nada, ed. 1997. Naše Lokve [Our Lokve]. Lokve: Općina Lokve.

Hardt, Michael. 2007. "Foreword. What Affects are Good for". In The Affective Turn. Theorizing the Social. Patricia Ticineto Clough and Jean Halley, eds. Durham, London: Duke University Press, ix-xiii.

Knežević, Rade and Renata Grbac Žiković. 2013. “Promjene gospodarskog značenja tranzitnog turizma u Gorskom kotaru" [Changes in the economic importance of transit tourism in Gorski Kotar]. Hrvatski geografski glasnik 75/1: 111-130. https://doi.org/10.21861/HGG.2013.75.01.06

Komadina, Rudolf. 2015. Lokve i Mrzla Vodica u borbi za slobodu od 1894. do 1945. [Lokve and Mrzla Vodica in the freedom struggle from 1894 to 1945]. Bilten 4. Lokve: Udruga antifašističkih boraca i antifašista Općine Lokve.

Lajić, Ivan and Sanja Klempić Bogadi. 2010. "Demografska budućnost Gorskoga kotara” [Demographic future of Gorski Kotar]. Migracijske i etničke teme 26/2: 191-212. 
Laloš, Željko. 2007. Stoara dejuonoška ženitaf (Stari delnički ženidbeni običaji) [Old marriage customs in Delnice]. Delnice: Etno-udruga "Prepelin'c".

Larkin, Brian. 2013. "The Politics and Poetics of Infrastructure". Annual Review of Anthropology 42: 327-343. https://doi.org/10.1146/annurev-anthro-092412-155522

Low, Setha M. 2009. "Towards an Anthropological Theory of Space and Place". Semiotica 175: 21-37. https://doi.org/10.1515/semi.2009.041

Low, Setha M. 2017. Spatializing Culture. The Ethnography of Space and Place. London, New York: Routledge. https://doi.org/10.4324/9781315671277

Low, Setha M. and Denise Lawrence-Zúñiga 2003. "Locating Culture". In The Anthropology of Space and Place. Locating Culture. Setha M. Low and Denise Lawrence-Zúñiga, eds. Malden etc.: Blackwell Publishing, 1-47.

Lukić, Aleksandar, Vuk Tvrtko Opačić and Ivan Zupanc. 2009. "The Other Side of the Zagreb - Rijeka Motorway. Socio-geographic Implications in the Rural Periphery of Croatia". Društvena istraživanja 18/1-2: 153-173.

Masquelier, Adeline. 1992. "Encounter with a Road Siren. Machines, Bodies and Commodities in the Imagination of a Mawri Healer". Visual Anthropology Review 8/1: 56-69. https://doi.org/10.1525/ var.1992.8.1.56

Masquelier, Adeline. 2002. "Road Mythographies. Space, Mobility, and the Historical Imagination in Postcolonial Niger". American Ethnologist 29/4: 829-856. https://doi.org/10.1525/ae.2002.29.4.829

Mesić, Stipe. 2004. The Demise of Yugoslavia. A Political Memoir. Central European University Press.

Pleše, Mirjana, ed. 2004. Lokvarski zbornik, 1 [The Lokve Anthology, 1]. Lokve: Općina Lokve.

Roseman, Sharon R. 1996. "How we Built the Road". The Politics of Memory in Rural Galicia". American Ethnologist 23/4: 836-60. https://doi.org/10.1525/ae.1996.23.4.02a00090

Saraiva, Clara. 2003. "Aldeia da Luz. Entre dois solstícios, a etnografia das continuidades e mudanças". Etnográfica 7/1: 105-130.

Senjković, Reana. 2016. Svaki dan pobjeda. Kultura omladinskih radnih akcija [A victory every day. The culture of Youth Work Actions]. Zagreb: Institut za etnologiju i folkloristiku, Srednja Europa.

Simone, AbdouMaliq. 2003. "People as Infrastructure. Intersecting Fragments in Johannesburg”. Public Culture 16/3: 407-429. https://doi.org/10.1215/08992363-16-3-407

Škrbić Alempijević, Nevena, Sanja Potkonjak and Tihana Rubić. 2016. Misliti etnografski. Kvalitativni pristupi i metode $v$ etnologiji i kulturnoj antropologiji [Thinking ethnographically. Qualitative strategies and methods in ethnology and cultural anthropology]. Zagreb: FF Press, hed-biblioteka.

Star, Susan L. 1999. "The Ethnography of Infrastructure". American Behavioral Scientist 43/3: 377-91. https://doi.org/10.1177/00027649921955326

Strohal, Rudolf. 1993 [1935]. Uz Lujzinsku cestu [By the Lujzijana road]. Rijeka: Tiskara Rijeka.

Webster's Encyclopedic Unabridged Dictionary of English Language. 1996. New Jersey: Gramercy Books. 


\section{LJUBAV NA CESTI I SJEĆANJA U VODI: AFEKTI U INFRASTRUKTURNIM PROSTORIMA U GORSKOME KOTARU}

Rad pokazuje različite načine transformacije prostora infrastruktura u Gorskome kotaru (Hrvatska) u simboličko mjesto, kroz afekte lokalnog stanovništva. Istraživanje je provedeno u kontekstu dviju infrastruktura: Lujzinske ceste, koja datira s početka 19. stoljeća i spaja gradove Rijeku i Karlovac, te brane u Lokvama i njezina prostranog umjetnog jezera, sagrađene u pedesetim godinama 20. stoljeća. Određeni događaji, scene, situacije, narativi, prakse i reakcije kao pokretači i posljedice afekata korišteni su kao temelj za analizu. Istraživanje pokazuje da ljudi doživljavaju različite vrste afekata, povezane s fizičkim karakteristikama infrastruktura i njihovim utjecajima, te ih izražavaju kroz književnost, razgovore, individualnu praksu i organizirane aktivnosti. Dok Lujzinska cesta, shvaćana kao kulturna baština, izaziva osjećaje ljubavi i poštovanja, brana i jezero tvore hibridno mjesto radosnih sjećanja na vrijeme gradnje brane, kao i onih tužnih na potopljena sela.

Ključne riječi: afekt, infrastrukture, stvaranje mjesta, Gorski kotar 